\title{
Agricultural Water Conservation in the High Plains Aquifer and Arikaree River Basin
}

\author{
Adam Prior ${ }^{1}$, Ramchand Oad ${ }^{1}$, Kristoph-Dietrich Kinzli ${ }^{2}$ \\ ${ }^{1}$ Department of Civil and Environment Engineering, Colorado State University, Fort Collins, USA \\ ${ }^{2}$ Department of Environmental and Civil Engineering, Florida Gulf Coast University, Fort Myers, USA \\ Email: aprior@skybeam.com
}

Received April 27, 2013; revised May 28, 2013; accepted June 19, 2013

Copyright (C) 2013 Adam Prior et al. This is an open access article distributed under the Creative Commons Attribution License, which permits unrestricted use, distribution, and reproduction in any medium, provided the original work is properly cited.

\begin{abstract}
Yuma County is the top crop producing County in Colorado that is dependent on groundwater supplies from the High Plains aquifer for irrigation. The Arikaree River, a tributary of the Republican River in eastern Colorado, is supplied with water from the High Plains aquifer. The Arikaree River alluvium is also a habitat for many terrestrial invertebrates and the threatened Hybognathus hankinsoni (Brassy Minnow). The constant demand on the High Plains aquifer has created declining water levels at the linear rate of $0.183 \mathrm{~m} /$ year with the deepest pool in the Arikaree River drying up in 8 to 12 years. In addition to the demands for habitats, the surrounding irrigated agricultural lands require water for crop production. These challenges are currently confronting farmers in eastern Colorado and this research presents possible alternatives to meet these demands. This research presents a combination water balance model, water conservation model, and water conservation survey results from farmers in eastern Colorado to identify alternatives to extend the life of the Arikaree River. The first alternative was to examine the reduction in irrigation water from removing the 18 alluvial irrigation wells that could extend the Arikaree River pools from drying up for 30 years. The other scenario found that water conservation practices with participation of $43 \%, 57 \%$, and $62 \%$ of farmers would extend the drying time to 20,30 , and 40 years, respectively. The final alternative studied was the required participation in conservation practices to stop the decline of the High Plains Aquifer. The analysis found that $77 \%$ participation of farmers in all conservation alternatives or reducing pumping by $62.9 \%$ would be necessary to stabilize the High Plains Aquifer.
\end{abstract}

Keywords: Agriculture; Conservation; Groundwater; Irrigation; Pumping; Water Balance

\section{Introduction}

Throughout the United States, and especially in Colorado, farmers confront the challenges of meeting water needs for crop production, while trying to maintain natural habitats and conserve dwindling water supplies. The Arikaree River is a tributary of the Republican River on the Great Plains of Eastern Colorado and is groundwater dependent with flows from the underlying High Plains aquifer. The river is characterized by an extensive gallery of mature riparian cottonwoods (Populus deltoids), welldeveloped refuge habitat for threatened fish species such as the Brassy Minnow (Hybognathus hankinsoni), as well as habitat for many terrestrial invertebrates sustained by water from the High Plains aquifer. The riparian habitat areas along the Arikaree River are a critical component of stream-riparian ecosystems in the Great Plains [1]. In addition to the demands for the maintenance of habitats, the surrounding irrigated agricultural land requires water as well. The irrigation water supply is groundwater pumped from the High Plains aquifer by high-capacity pumps. In recent years, the river has become a series of disconnected pools or has dried up entirely during the late summer. To sustain both a precarious regional agricultural economy and an aquatic/riparian ecosystem, both dependent on groundwater for existence, there must be tradeoffs to preserve this important resource. The research presented here provides practical guidelines for water conservation, water management practices, and identified feasible and realistic conservation measures for farmers in Eastern Colorado.

\subsection{Study Area}

The research study area was located in Yuma County, Colorado with the Yuma County border as the eastern and western boundaries. The north and south boundaries constitute the groundwater divide as shown in Figure 1 
from geology and groundwater resources of Yuma County, Colorado, USGS water-supply paper 1539-J [2].

The Arikaree River has headwaters on the plains in eastern Colorado that flow northeast through Kansas before joining the Republican River in the southwest corner of Nebraska. The river is a fluctuating stream [4], primarily sustained by inflow from springs or seeps from the High Plains aquifer and by storm events. The average annual stream flow from 1932 to 2009 has decreased significantly as shown in Figure 2. After the introduction of groundwater pumping in the 1960's, there is a marked decline in the average annual flows.

The High Plains aquifer is a part of the Ogallala Aquifer, the largest aquifer in the United States. Colorado only has $4 \%$ of the High Plains aquifer available for usable water $[5,6]$. Since the High Plains aquifer both feeds and connects to the Arikaree River, the geomorphology has a significant effect on flow regimes [7]. The Ogallala

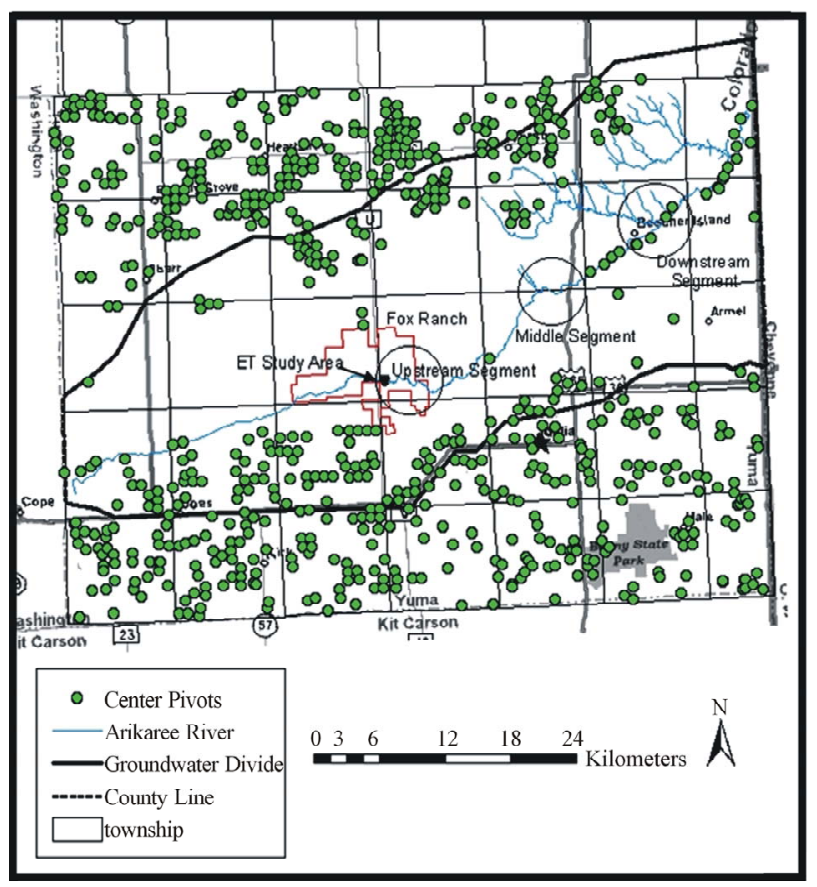

Figure 1. The Arikaree River basin within southern Yuma County [3].

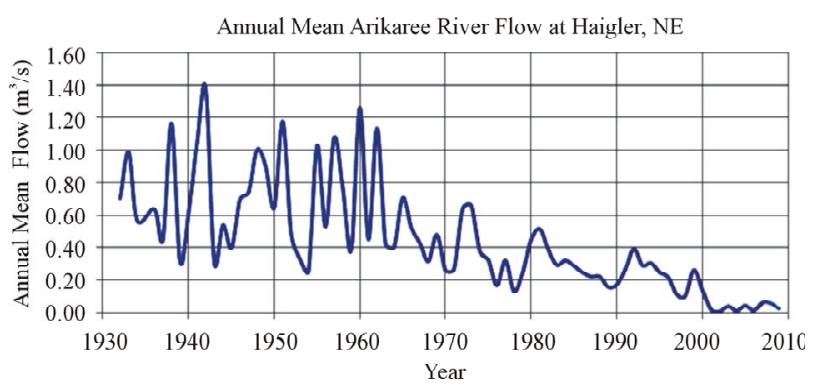

Figure 2. Annual average stream flows in the Arikaree River at Haigler, Nebraska from 1932 to 2009 [12].
Formation overlies the Pierre Shale and is made of layers of sand, gravel, clay, limestone, and sandstone [2].

Research has shown that the water table is declining by about $0.25 \mathrm{~m} / \mathrm{yr}$ near the Arikaree River [8] with the average rate of decline of the water table at $0.34 \mathrm{~m} / \mathrm{yr}$ [9]. Reference [10] determined an annual water table decline of $0.3 \mathrm{~m}$ in the High Plains. Data collected by the Colorado Division of Water Resources [11] found the average water table decline of $2.08 \mathrm{~m}$ from 1988 to 2002 that equaled a decline of $0.15 \mathrm{~m}$ per year.

The Arikaree Groundwater Management District has reported a decline $1.14 \mathrm{~m}$ in saturated thickness from 1997 to 2004 or $0.16 \mathrm{~m} /$ year [13].

\subsection{Water Conservation}

Water conservation can be defined as long-term increase in the productive use of a water supply without compromising the desired water services. Water conservation in terms of agricultural production can also mean more efficient water use, transmission and distribution system efficiency improvements, reduced evaporation and runoff, and the production of crops with reduced water requirements. Opportunities to address the concurrent water needs of irrigators and the stream flow requirements for fish habitat are many and diverse. A comprehensive literature review was completed about the conservation methods and practices used throughout the country and in the arid western United States under conditions similar to the High Plains aquifer and Arikaree River alluvium. The water conservation alternatives were divided into five different categories that included field conservation practices, irrigation conservation practices, management conservation practices, water conservation programs, and lower consumptive use crop selection.

Field practices for water conservation increase the amount of water stored in the soil profile by trapping or holding rain where it falls, or where there is some small movement as surface runoff [14]. Local farmers in a water conservation survey identified the no-tillage field practice as the most feasible conservation measure with approximately $20 \%$ of the corn acres in produced in the United States utilizing no-tillage practices.

No-till field management can save 10.2 to $12.7 \mathrm{~cm}$ of water for corn in Kansas with the combined growing and non-growing season [15]. In eastern Colorado from 2000 to 2004 , corn crop residue also showed to have a significant effect during the non-growing season (October to April) by increasing stored soil water by $5.08 \mathrm{~cm}$ when compared to conventional stubble mulch [16]. Wheat stubble will increase soil water storage by 5.08 to $6.35 \mathrm{~cm}$ when compared to bare soil [17]. Wheat straw and no-till corn stover will save 6.35 to $7.62 \mathrm{~cm}$ of water from early June to the end of the growing season [18]. In Akron, Colorado, it was determined that no-till with wheat resi- 
due accumulated $11.68 \mathrm{~cm}$ of recharge over the fall, winter, and spring compared to conventionally tilled wheat residue that only had $6.35 \mathrm{~cm}$ of recharge for a total savings of $5.33 \mathrm{~cm}$ during the non-growing season [16].

Irrigated agriculture uses approximately $80 \%$ of all the available water supplies in the Western United States [19-22]. Center pivot sprinkler irrigation systems are the most common form of irrigation used in the High Plains of Colorado [22]. About $90 \%$ of the irrigation systems use center pivots and pump from the High Plains aquifer $[23,24]$. The development of multi-functional systems such as low energy precision application (LEPA) allow farmers to apply water and also practice precision application of herbicides, pesticides, and fertigation [25]. The LEPA systems are highly efficient and can achieve application efficiencies in the $95 \%$ to $98 \%$ range [26] and [27] while other research suggests efficiency ranges from $80 \%$ to $95 \%$ depending on management [22].

A common water saving upgrade of center pivots is to reduce operating pressure and apply water within or below the crop canopy. Upgrading sprinkler systems to low pressure heads with drop tubes reduces evaporation from the plant surface, especially for corn [28]. If properly utilized, these improvements can result in water savings of $10 \%$ to $15 \%$ compared to traditional center pivot sprinkler applications [22].

In eastern Colorado, the climate is semi-arid requiring some level of irrigation during drought years to maximize certain crop yields. Water conservation survey results of eastern Colorado farmers found that drought tolerant crops were the most preferred and feasible water conservation alternative. Today's best drought-tolerant crop hybrids, developed through conventional breeding, often yield within $75 \%$ to $80 \%$ of their average lowstress yields under drought stress. Other research comparing hybrid yields for the last three decades showed that genetic improvements have increased yields $2.6 \%$ per year [29] due to hybrid water stress tolerance [30]. Reference [31] discovered a new corn hybrid that stresssed at $50 \%$ of crop required ET produced $27 \%$ higher yields, but with adequate water, both hybrids produced similar yields. Corn breeders have found a new germplasm that can reduce water usage by $10 \%$ [32]. Xu and Lascano [33] found new corn hybrids that produce the same silage yield with a $75 \%$ crop water requirement (CWR) [32].

A wide range of programs to conserve water through state and national agencies exist in Colorado, in Yuma County, and in the Arikaree River basin. The 2007 Census of Agriculture in Yuma County Profile [23] said that 432 farms out of the 970 total farms in Yuma County participated in agricultural conservation programs. The farm participation in conservation programs increased from $28 \%$ in 2002 to $45 \%$ in 2007 [23]. Water conservation survey results of eastern Colorado farmers found that water use limits were considered a feasible water conservation alternative. Reference [34] conducted research over a 10-year period showing that applying $15.2 \mathrm{~cm}$ per crop using limited irrigation can achieve winter wheat yields at $99 \%$, corn yields at $86 \%$, and soybean at $88 \%$ of the full irrigation yields. With proper management of $25 \%-50 \%$ water application reductions, the income reduces by only $10 \%-20 \%$ [34]. Another successful water use limit program by the Nebraska Upper Republican Natural Resources District (URNRD) allows $184.2 \mathrm{~cm}$ $(36.8 \mathrm{~cm} /$ year) of water in any five-year period [35]. The water use limits have required farmers to be more resourceful and creative in managing water allocations. Research from 1986 to 1999 demonstrated that, if required, farmers could survive with less water usage because they were only using $80 \%$ of the allocated water for the fiveyear period.

Low consumptive use crops can be cool season crops that are subject to lower atmospheric demand that directly relates to lower ET rates. Switching to crops with shorter growing seasons will reduce crop water and irrigation demands in order to conserve water. This research has identified lower water use crops as any crop that has a lower consumptive use than corn, because corn is the dominant irrigated crop grown in eastern Colorado.

\section{Materials and Methods}

\subsection{Water Balance}

To address water shortages and impacts to the Arikaree River, a water balance model was developed to compare pre-development (before pumping), post-development (after pumping), future conditions, and the possible impacts of water conservation. This water balance does not account for spatial and temporal variability in parameters such as recharge, evapotranspiration, and pumping, but provides the initial analysis in understanding and modeling the aquifer and river hydrologic system. The model was broken into three distinctive model areas that include the regional High Plains aquifer, the alluvium model, and a complete model combining the High Plains aquifer and alluvium. Figures 3 and $\mathbf{4}$ show the pre- and post-development model parameters used in the High Plains aquifer and alluvial aquifer with their respective data sources.

Stream inflow from the aquifer was assumed to be $10 \%$ of the average stream flow data measured at USGS gauging station \#6821360 (Haigler, NE) from 1933 to 1960 based on previous research done by Squires [8]. Stream outflow was the average stream flow measured at USGS gauging station \#6821360 (Haigler, NE). The constant flux boundaries specified at the upstream boundary and at the downstream boundary of the alluvium estimations came from the 1958 head contour map [2]. The hy- 


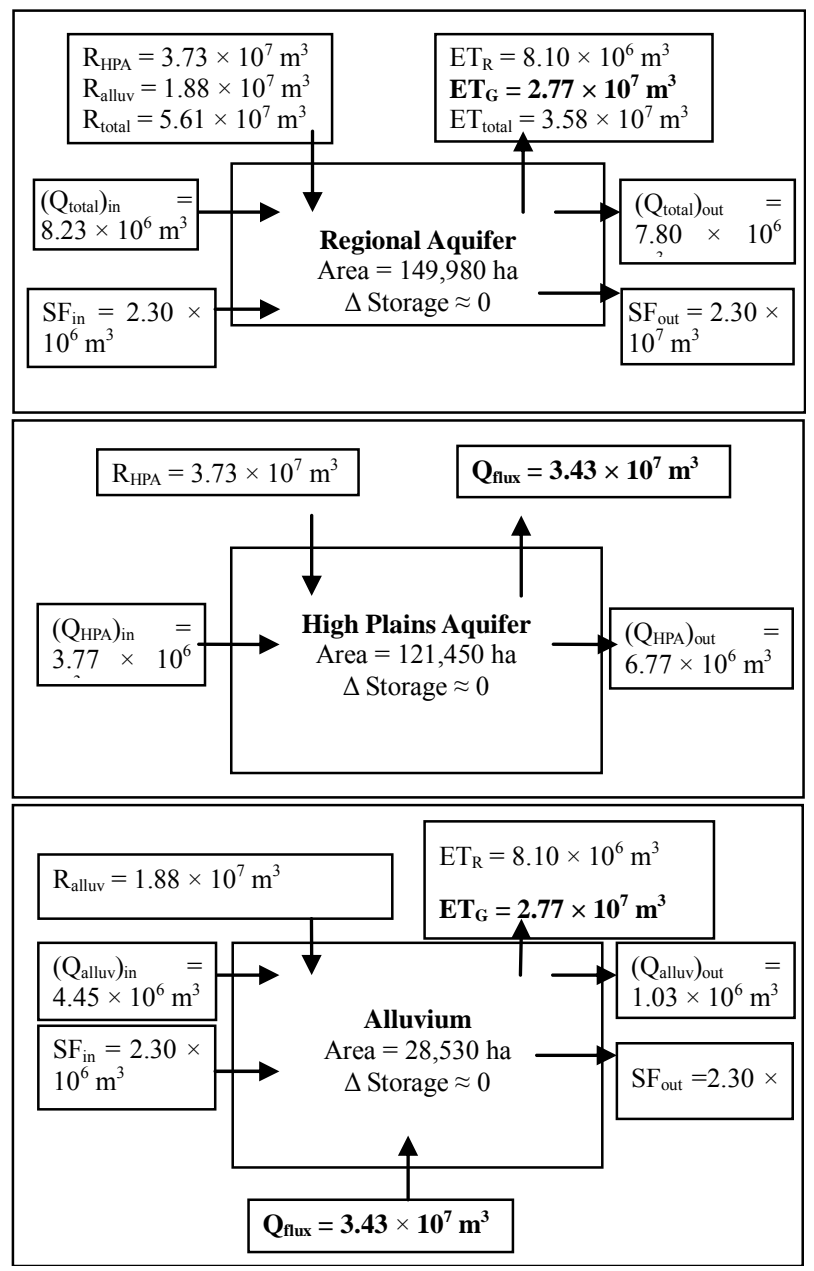

Figure 3. Initial water balance for the regional aquifer, High Plains aquifer, and the alluvial aquifer (terms in Bold solved in the pre-development water balance).

draulic conductivities used in the groundwater boundaries and flows between hydraulic units were found by [36] with the alluvium hydraulic conductivities being three times higher than in the surrounding areas [2,36]. Riparian evapotranspiration research by [37] established an average value of $89.2 \mathrm{~cm}$ in the 2006 growing season. This riparian evapotranspiration value affected an area of 909 ha as delineated by [3]. The alluvium grass evapotranspiration was a calibration constant used to balance the alluvial water balance. The alluvium grass evapotranspiration was assumed to be $10 \mathrm{~cm} / \mathrm{yr}$ over the remainder of alluvium (27621.5 ha). Reference [38] found in Akron, Colorado that native grasses used $9 \mathrm{~cm}, 10.6$ $\mathrm{cm}$, and $19 \mathrm{~cm}$ respectively in 1966, 1966, and 1967 . The alluvium grass evapotranspiration area was the remaining area in the alluvium outside the riparian area for a total area of 27,621 ha $(28,530$ ha - 909 ha). Recharge to the alluvium was determined to be approximately $15 \%$ from research completed by [39] and the regional water balances [8]. For the alluvial aquifer, the estimation of the

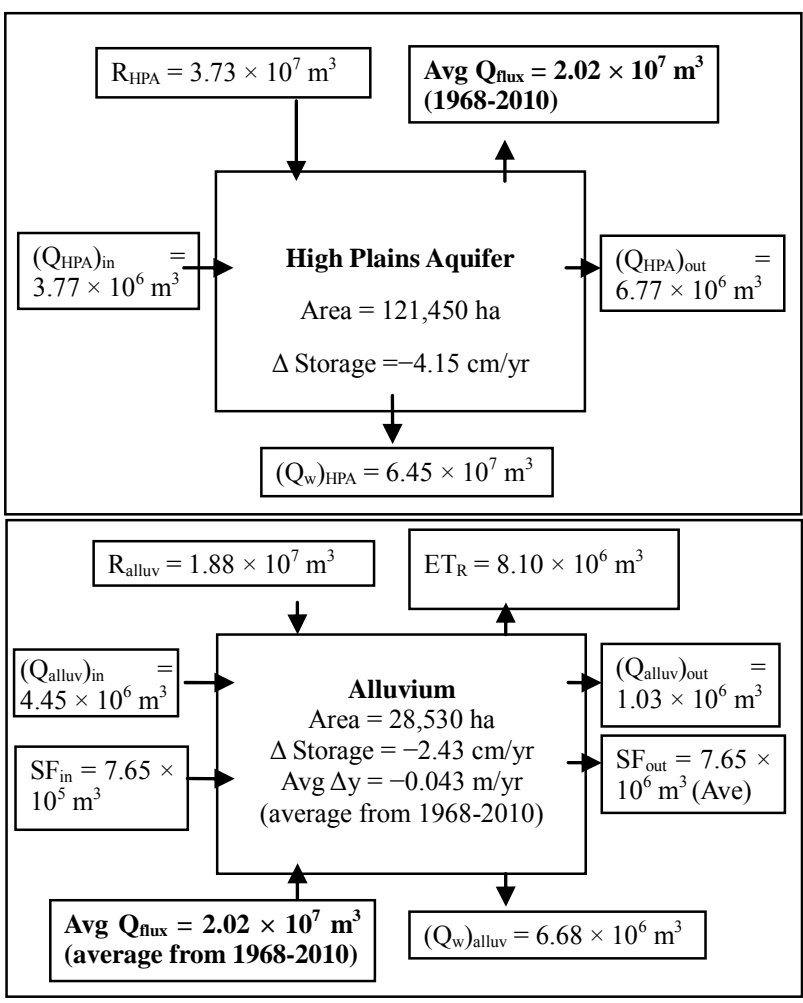

Figure 4. Post-development water balance for the High Plains aquifer and the alluvial aquifer (terms in bold Solved for in post-development the water balance).

uniform recharge was to be $6.6 \mathrm{~cm}, 15 \%$ of the average precipitation of $44 \mathrm{~cm}$ based on a lysimeter in the alluvium along the South Platte in Fort Morgan County, Colorado $[8,39]$. Recharge to the High Plains aquifer was determined to be approximately $7 \%$ of the average precipitation of $44 \mathrm{~cm}$ from 1932 to 1960 from research by [40,41].

The specified constant flux boundaries at the upstream boundary and at the downstream boundary of the High Plains aquifer estimates came from the 1958 head contour map [2]. Since the stream flow gauging station is approximately 11,300 meters downstream of the Yuma County boundary, the water balance did not use all of the groundwater flow leaving the boundary. The [2] contours shows the groundwater entering the river prior to the gauging station so they were not used in calculations to avoid double counting water flows. The groundwater flux out of the High Plains aquifer and into the alluvial aquifer was estimated from the pre-development calibrated regional models to match well data and to balance each region.

A pre-development (1933-1960) water balance model was created to determine model calibration groundwater flux between the model boundaries Figure 3. The predevelopment water balance has negligible storage change over time $(\Delta \mathrm{S}=0)$ for prior to 1960 [8]. A second water 
balance (1968-2009) was developed by utilizing the predevelopment water balance and current irrigation pumping rates. The post-development water balance model added average (2002-2006) irrigation well pumping output of 71.2 million cubic meters [3,37,42,43].

Figure 4 illustrates the average water balance for the post well-installation period (post-1968). It was assumed that recharge for the alluvium will increase from $15 \%$ to $20 \%$ because of the increase capacity for infiltration in the alluvium aquifer (1975 to 2010). This calibration was to align the water balance model and the measured well water elevation data. Historically, the main discharge out of the basin was the stream flow that significantly decreased after the installation of irrigation wells. The additional water entering the alluvium represents recharge to the aquifer or evapotranspiration out of the basin. Therefore, the recharge was assumed to linearly increase from 1968 to 1974 to a recharge rate of $20 \%$.

Figure 5 shows a two-dimensional diagram of the HPA and the alluvial aquifer interaction with variables used in Darcy's Law calculations.

To estimate the groundwater flux into the alluvium throughout time, a one-dimensional form of Darcy's Law calculated the flow in the $\mathrm{x}$-direction per unit width as shown in Equation (1):

$$
\mathrm{Q}_{\text {flux }}=\mathrm{Q}_{\mathrm{x}}=-\mathrm{Kh} \frac{\mathrm{dh}}{\mathrm{dx}}
$$

where:

$\mathrm{Q}_{\text {flux }}$

$=$ groundwater flux from the HPA to the alluvium $\left(\mathrm{L}^{2} / \mathrm{t}\right)$

$$
\mathrm{K}=\text { hydraulic conductivity }(\mathrm{L} / \mathrm{t})
$$

$\mathrm{h}=\mathrm{h}(\mathrm{x}, \mathrm{t})$

$=$ the saturated thickness of the aquifer at $\mathrm{x}$ at time $\mathrm{t}(\mathrm{L})$

$$
\mathrm{dh} / \mathrm{dx}=\text { hydraulic gradient }(\mathrm{L} / \mathrm{L})
$$

Equation (1) also assumed the Dupuit-Forcheimer assumtions [44] are valid. Integrating Equation (1) with the

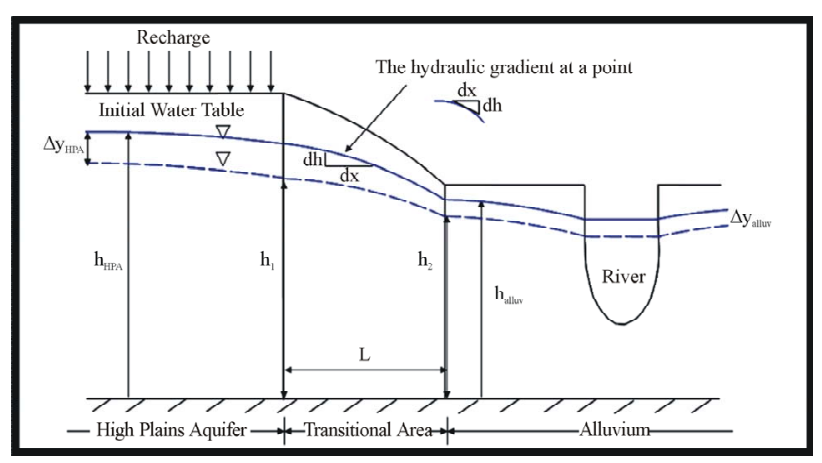

Figure 5. 2-D Schematic showing the relationship between the High Plains aquifer and the alluvial aquifer. boundary conditions:

at $\mathrm{x}=0, \mathrm{~h}(0, \mathrm{t})=\mathrm{h}_{1}$

at $\mathrm{x}=\mathrm{L}, \mathrm{h}(\mathrm{L}, \mathrm{t})=\mathrm{h}_{2}$

Results in

$$
\mathrm{Q}_{\mathrm{flux}}=\frac{\mathrm{K}}{2 \mathrm{~L}}\left(\mathrm{~h}_{2}^{2}-\mathrm{h}_{1}^{2}\right)
$$

where:

$\mathrm{L}=$ length of the transitional area $(\mathrm{L})$

$\mathrm{h}_{1}(\mathrm{x}, \mathrm{t})=\mathrm{h}_{1}(0, \mathrm{t})$ saturated thickness in the HPA at $\mathrm{x}$

$$
=0 \text { at year } \mathrm{t}
$$

$\mathrm{h}_{2}(\mathrm{x}, \mathrm{t})$

$=\mathrm{h}_{2}(\mathrm{~L}, \mathrm{t})$ saturated thickness in the alluvial aquifer at $\mathrm{x}$

$=\mathrm{L}$ at year $\mathrm{t}$

$\mathrm{t}=$ time in years, $\mathrm{t}=1933$ to 2009

The hydraulic head in the High Plains aquifer is larger than in the alluvium because the High Plains aquifer has a large recharge area in the dune sands north of the river while the river and alluvium are discharge areas, particularly in predevelopment. Hydraulic head in the High Plains aquifer $\left(\mathrm{h}_{1}\right)$ and hydraulic head in the alluvial aquifer $\left(\mathrm{h}_{2}\right)$ both change with time due to the change in aquifer storage and precipitation levels. The decline in the High Plains aquifer due to irrigation pumping will result in a decreasing flux into the alluvium aquifer over time. Application of Darcy's law would suggest that the change in groundwater flux from the High Plains aquifer to the alluvium is not linear over time.

The analysis assumed the slope of the water table towards the river in the alluvium and High Plains aquifer was small to satisfy the Dupuit-Forcheimer assumptions that all flows are horizontal and the hydraulic gradient causing discharge is proportional to the slope of water table [44]. The research assumed the changes in the alluvial water table elevation occurred uniformly across the entire alluvium.

To have confidence in the changes in water table elevations over time, both Darcy's law and the yearly water balance had to be satisfied. For a yearly water balance:

$$
\Delta y(t)=\frac{\text { Out }- \text { In }}{\text { Area }(\text { Sya })}
$$

where:

Out $=$ Flow out of model boundary

In $=$ Flow into model boundary

Area $=$ Area of model boundary

Sya $=$ Specific yield of aquifer

For convenience, this equation was written so that a positive value of $\Delta y(t)$ implies a decline in the water table. For the High Plains aquifer: 


$$
\begin{aligned}
& \Delta \mathrm{y}_{\mathrm{HPA}}(\mathrm{t}) \\
& =\frac{\mathrm{Q}_{\text {flux }}(\mathrm{t})+\left(\mathrm{Q}_{\mathrm{HPA}}\right)_{\text {out }}+\left(\mathrm{Q}_{\mathrm{w}}\right)_{\mathrm{HPA}}-\mathrm{R}_{\mathrm{HPA}}-\left(\mathrm{Q}_{\mathrm{HPA}}\right)_{\text {in }}}{121,450 \text { Sya }}
\end{aligned}
$$

The units in Equations (3) and (4) are $\mathrm{m}^{3} / \mathrm{yr}$ in the numerator and $\mathrm{m}^{2}$ in the denominator.

For the alluvial aquifer:

Research conducted by [8,37] found the average Sya to be 0.124 , using storm events and groundwater modeling. In addition, wells were installed over a period of years so that $\mathrm{Q}_{\mathrm{w}}$ for both the alluvium and the High Plains aquifer increased from $60 \%$ in 1968 to the final constant pumping value in 1975 .

The water table elevation at the beginning of each season was determined by subtracting the change from the water table elevation at the beginning of the previous season as shown:

$$
\begin{aligned}
& \mathrm{h}_{\text {HPA }}(\mathrm{t})=\mathrm{h}_{\text {HPA }}(\mathrm{t}-1)-\Delta \mathrm{y}_{\text {HPA }}(\mathrm{t}) \\
& \mathrm{h}_{\text {alluv }}(\mathrm{t})=\mathrm{h}_{\text {alluv }}(\mathrm{t}-1)-\Delta \mathrm{y}_{\text {alluv }}(\mathrm{t})
\end{aligned}
$$

where:

$\mathrm{h}_{\mathrm{HPA}}(\mathrm{t})=$ saturated thickness in the HPA at time $\mathrm{t}$

$\mathrm{h}_{\text {alluv }}(\mathrm{t})=$ saturated thickness in the alluvium at time $\mathrm{t}$

Equations (1) through 4 were used to calculate yearly water table levels changes in the model region. In the first year, the groundwater flux was from the initial water balance and was entered into Equations (3) and (4) to determine the water table elevation changes for the following year. Then the water table elevation changes were entered into Equations (4a) and (4b) to determine the saturated thickness in both aquifers. At that point, equation 2 was used to determine the new groundwater flux. Introducing this new groundwater flux into the next equation allowed for the calculation of water table changes for the following year. Repeating this process for each year from 1968 to 2010 resulted in a yearly groundwater flux, yearly water table elevation in the High Plains aquifer, and yearly water table elevation in the alluvial aquifer. This water balance model was calibrated to match alluvium well data and High Plains aquifer well data. The water balance model projections beyond 2010 appear in future sections. The length of the transitional area, L, in Equation (2) was unknown, but calibrated based on $\mathrm{Q}_{\text {flux }}$ from the water balance model. The planar length on each side of the river where the High Plains aquifer is in contact with the alluvial aquifer is approximately $12,940 \mathrm{~m}$, that would correspond to the average distance from the edge of the alluvium to the monitoring wells in the High Plains aquifer.
Calculations of the decline in water levels in the High Plains aquifer using the method described above were compared to measured well data. Figure 6 shows High Plains aquifer water elevation data at Well \#9380 and the calculated water balance model water elevations. The calculations of the water table elevations started at the initial water table elevation that occurred at Well \#9380. This well was chosen for this research because it was used in previous research by [8] and had water levels elevations for the entire post-development modeling (1968 to 2009).

Results for the alluvial aquifer are more uncertain and variable due to varying inputs from the High Plains aquifer. Figure 7 shows the calculated water balance model as compares to the actual measured water table levels in three alluvium wells. Water level data was very limited within the alluvium with only three wells with data and

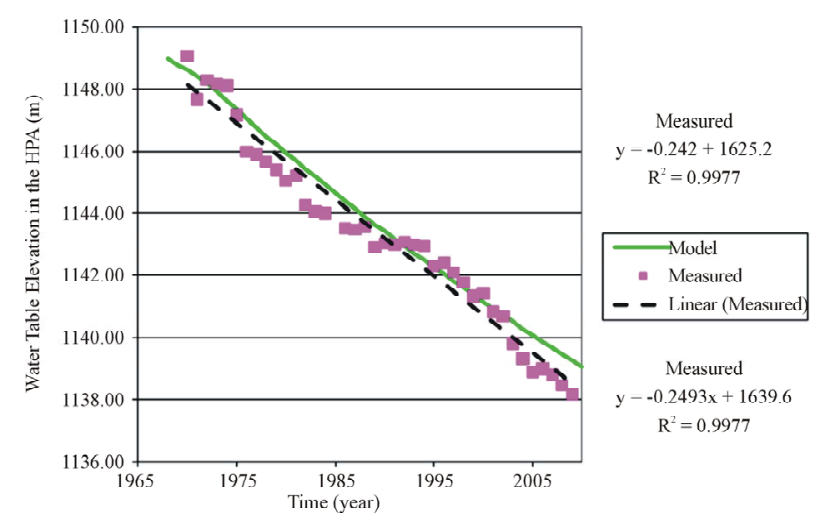

Figure 6. Measured water elevation and calculated water table elevation for one well in the High Plains aquifer.

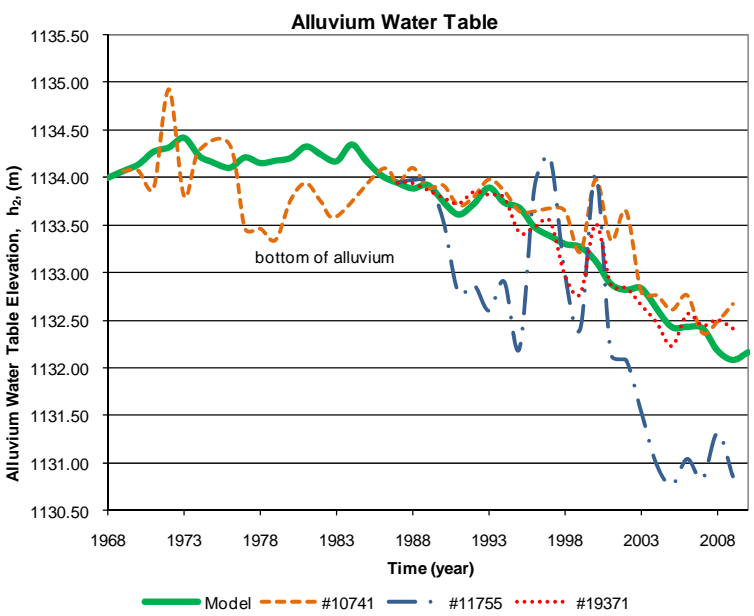

Figure 7. Measured water elevations for the only three Wells in the alluvium and calculated alluvium water elevations in Yuma County.

$$
\Delta \mathrm{y}_{\text {alluv }}(\mathrm{t})=\frac{\mathrm{ET}_{\mathrm{R}}+\mathrm{ET}_{\mathrm{G}}+\mathrm{SF}_{\text {out }}+\left(\mathrm{Q}_{\text {allum }}\right)_{\text {out }}+\left(\mathrm{Q}_{\mathrm{w}}\right)_{\text {alluv }}-\mathrm{R}_{\text {alluv }}-\left(\mathrm{Q}_{\text {alluv }}\right)_{\text {in }}-\mathrm{SF}_{\text {in }}-\mathrm{Q}_{\text {flux }}(\mathrm{t})}{28,530 \text { Sya }}
$$


only one well with data from the entire post development time period. Alluvial well \#10741 was utilized to calibrate the water balance model within the alluvium.

The measured water level data in the High Plains aquifer and alluvial aquifer displayed nearly identical characteristics to the water balance models. The Nash-Sutcliffe modeling efficiency statistic was utilized to compare the measured and predicted water levels.

The Nash-Sutcliffe model evaluation statistic is widely used to validate various models [45-47]. The Nash-Sutcliffe model efficiency statistic is defined in Equation (5).

$$
\mathrm{E}=1-\frac{\sum_{\mathrm{t}=1}^{\mathrm{T}}\left(\mathrm{Q}_{\mathrm{o}}^{\mathrm{t}}-\mathrm{Q}_{\mathrm{m}}^{\mathrm{t}}\right)^{2}}{\sum_{\mathrm{t}=1}^{\mathrm{T}}\left(\mathrm{Q}_{\mathrm{o}}^{\mathrm{t}}-\overline{\mathrm{Q}}_{\mathrm{o}}\right)^{2}}
$$

In this equation $Q_{o}$ is an actual measurement, $Q_{m}$ is the model predicted value, and $\mathrm{Q}_{\mathrm{o}}^{\mathrm{t}}$ is actual measurement at time t. Nash-Sutcliffe efficiencies can range from $-\infty$ to 1. An efficiency of one $(E=1)$ corresponds to a perfect match of modeled values to the measured data. An efficiency of zero $(\mathrm{E}=0)$ indicates that the model predictions are as accurate as the mean of the observed data. Efficiency less than zero $(\mathrm{E}<0)$ occurs when the observed mean is a better predictor than the model [45]. In general, a Nash-Sutcliffe efficiency of 0.70 indicates that a model can adequately predict measured values. The High Plains aquifer water balance model and measure data from well \#9380 have a Nash-Sutcliffe efficiency of 0.95 from 1968 to 2009. The alluvial aquifer and water balance model has a Nash-Sutcliffe efficiency of 0.46 from 1968 to 2009. This value is much lower due the variability and fluctuation of the water levels from 1968 to 1985 . This variability is due to the annual hydrologic conditions and aquifer water being released from storage. The Nash-Sutcliffe efficiency is 0.68 from 1985 to 2009 due to the better correlation of the water balance model and the alluvial well data.

Shallow alluvial groundwater stage directly relates to pool depth across six pairs of wells and pools in the upstream segment from April through October 2007. As the groundwater stage declined during the summer, pool depths also declined. Falke, Fardel, and Griffin [42,49], and [43] found a strong correlation between the alluvial water table and the pool depths. These observations showed a direct relationship between pool stages in the Arikaree River and the alluvial groundwater levels [49]. The deepest pool in the upstream section in 2006 was 1.5 $\mathrm{m}$. Therefore, for these modeling efforts we assume the bottom of the pool was approximately $1.5 \mathrm{~m}$ below the water table elevation in 2006.

\subsection{Water Conservation Model}

A water conservation model was created using data from previous research $[3,8,37,42,49]$. Other data used in the water conservation model was the current participation of local farmers in the noted conservation alternatives that include field conservation practices, irrigation conservation practices, management conservation practices, water conservation programs, and lower consumptive use crop selection. The final water conservation model parameter was the possible future participation of local farmers in water conservation that provides the constant for all alternatives. Modifying this parameter determined what impacts all the participation levels (1\% to $100 \%)$ would have on the groundwater balance models.

The crop water requirements were calculated by utilizing a collection of reference ET data from the Colorado Agricultural Meteorological Network (CoAgMet). Reference [48] is a network of automatic weather stations distributed across Colorado with data since 1992. The weather stations selected for this research were locations throughout the research area characterized as an irrigation area. The CoAgMet used the Kimberly-Monteith method to estimate crop water use for corn and dry beans. The crop water requirements were $64.2 \mathrm{~cm}$ for corn and $55.8 \mathrm{~cm}$ for dry beans. Reference [23] found that in Yuma, County that approximately $52 \%$ of all the crops harvested and $75 \%$ of all the irrigated crops were corn providing the baseline for conservation measures. The water conservation calculations in the irrigation practices, management practices, programs, and crop selection used corn as the baseline. Conservation irrigation practices typically increase the application efficiency with the water savings calculated based on the corn water requirements. The conservation management practices can reduce a percentage of the corn water requirements to calculate the total water savings. The programs section and the crop selection water savings calculations were based on corn being grown throughout Yuma County.

\subsection{Conservation Survey}

A water conservation survey was developed from multiple sources, including consultations with local agricultural experts and a comprehensive literature review of conservation methods. The literature review focused on research conducted in the arid western United States and Colorado that could be implemented in the Arikaree River basin. The purpose of the surveys was to identify the most feasible conservation methods for farmers in eastern Colorado. The surveys were critical to ensure that the communities completely engage in the research in order to successfully gain local insight into feasible conservation measures.

The survey was broken into seven sections: General Farm Information, Field Practices, Irrigation System, Management Practices, Programs, Crop Selection, and Demographic Information. The water conservation sur- 
veys were distributed to 227 farmers in eastern Colorado, 41 surveys were returned for an $18 \%$ response rate. The top feasible conservation alternatives identified by local farmers include: no-tillage for the field practices; installation of low-pressure sprinkler packages for irrigation systems; planting crops that use less water (i.e. drought tolerant crops) for the management practices; utilization of water limit incentive conservation programs; and planting lower water use crop such as dry beans to replace the corn predominantly grown on approximately $52 \%$ of all croplands in Yuma County. These water conservation survey results directed the water conservation analysis and water balance analysis on the High Plains aquifer and alluvial aquifer.

The future water balance modeling utilized average or constant values for all parameters projected into the future. For example, the stream flow out was linearly decreased at a rate of $12,007 \mathrm{~m}^{3} /$ year for the best-fit line of the stream flow for the last 10 years. An average parameter used in the future water balance modeling was the precipitation data average from 1932 to 2009 of 0.44 meters. The actual future water levels in the High Plains aquifer fluctuated due to varying climatic conditions such as droughts and wet years. All future modeling projections do not account for possible temporal climate change. The water levels of the High Plains aquifer and alluvial aquifer have significant impacts from recharge that are directly proportional to precipitation. Since large-scale agricultural irrigation began in Yuma County during the $1960 \mathrm{~s}$, the volume of groundwater used for irrigation has been relatively constant since 1975. In the [23] the irrigated land in Yuma County showed a decrease of $0.7 \%$ from 2002 to 2007 . The current irrigation pumping rates within the Arikaree River basin were assumed constant for forecasting.

\section{Results}

The results for the High Plains aquifer are relatively straightforward, based on the measured data, and modeled information. The existing irrigation well water levels from this study indicate the High Plains aquifer is currently declining at $0.249 \mathrm{~m} /$ year (1968 to 2009). The water balance model of the High Plains aquifer estimated groundwater decline was $0.242 \mathrm{~m}$, which is similar to the measured decline rate (Figure 6). Although a straight line can approximate the water table decline in the High Plains aquifer, the water table decline in the alluvium appears to be nonlinear.

The existing alluvium well data suggest that from 1968 to approximately 1985 there was a slight decline in the alluvium water levels with fluctuations from climatic patterns (Figure 7). This could indicate the water in the alluvial aquifer was being released from the storage to supplement the lack of water from the High Plains aqui- fer flux. In approximately 1985, the alluvium water table established new declining water table equilibrium in correspondence to the declining High Plains aquifer.

The goal of the modeling was to match the alluvial decline from 1985 to 2009 . There were only 3 alluvial irrigation wells with water table data and only one well (\#10741) with data for the entire post-development modeling. The other two wells only had water table data from 1987 to 2009 (Figure 7). The well data for \#19371 and \#10741 have very similar linear declines from 1987 to 2009 so calibration of the model used these wells. The well data from \#11755 is believed to be flashier due to the Pierre Shale geology located near the Colorado and Kansas bounder. The fluctuations of the alluvial water table directly related to the precipitation and stream flow in the Arikaree River Basin. This knowledge about the water table fluctuation leads to the conclusion that the alluvium has had a steady decline in water levels since 1985. The average decline of the alluvial water table from 1985 to 2009 was $0.079 \mathrm{~m} /$ year using data from wells \#10741 and \#19371. Falke [49] took a census of all refuge pool habitat within each of the three segments during late July, the period of lowest connectivity, from 2005-2007. No pools were present in the downstream segment during any of the surveys. In that time range, there were 172 to 218 pools identified in the upstream segment that contained water. The middle segment had between 27 to 35 pools surveyed for habitat [49]. Overall, the upstream segment contained significantly more fish habitat pools than the middle segment during the driest portion of 2005 to 2007 [49]. Given the higher incidence of drying in the downstream and middle segments [50], we chose to model only the upstream portion of the basin where the alluvial aquifer directly connects to the High Plains aquifer, and where essential habitats for fish are most likely to persist into the future.

The first scenario examined the impacts of no changes to the current water usage and pumping rates throughout the High Plains aquifer and the alluvium. The High Plains aquifer will continue to decline at a linear rate of approximately $0.183 \mathrm{~m} /$ year (future projections). This rate is a lower decline rate than the measured rate of $0.249 \mathrm{~m} /$ year from 1968 to 2009 (Figure 8). A possible reason for this reduced decline is that the High Plains aquifer saturated thickness is decreasing and therefore the flow out of the High Plains aquifer is decreasing. The alluvial aquifer decline starts out slowly throughout the 1960's and 1970's and increases with time (1985 to 2009) because the alluvial aquifer is sensitive to changes in the groundwater flux (Figure 9). When less water feeds the alluvium, more water is taken from storage causing the water table elevation to decline. The modeling data matches well with water level data from well \#10741. The change in groundwater flux from the High Plains 


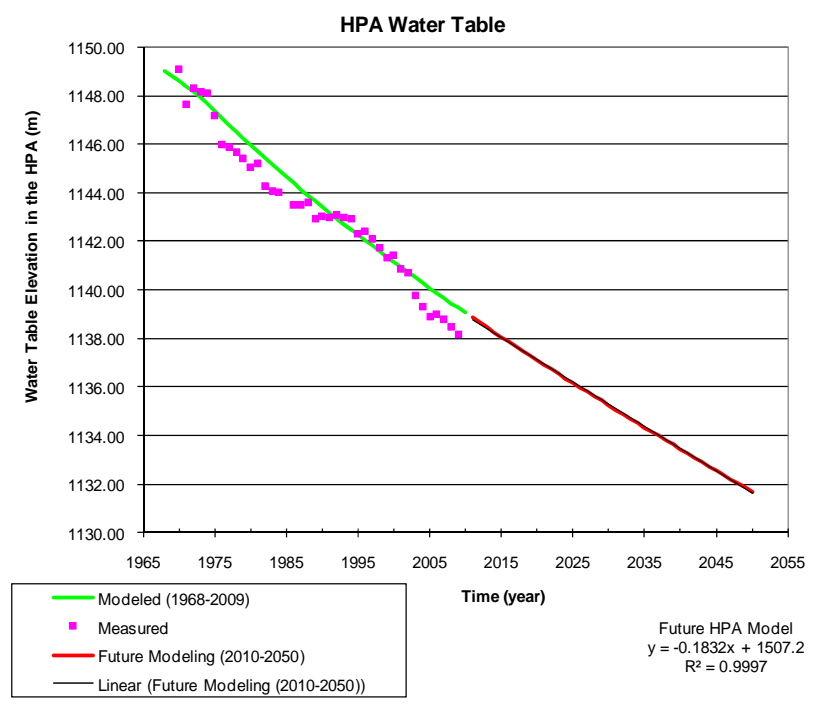

Figure 8. Alluvium aquifer water balance model with no changes and projected into the future to 2050 .

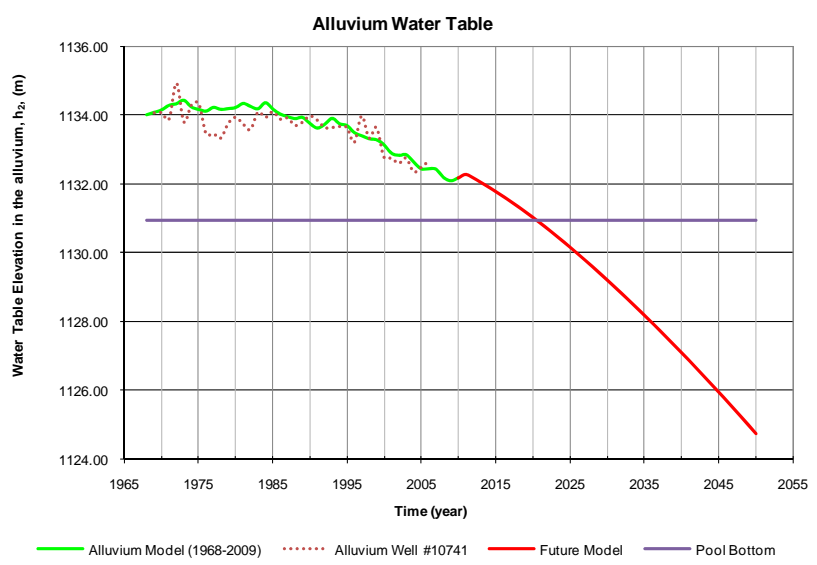

Figure 9. High Plains aquifer water balance model with no changes and projected into the future to 2050 .

aquifer to the alluvium is non-linear decline. The estimated time-to-drying for the deepest pool in the upper segment varies from approximately 8 to 12 years depending on interactions of the riparian habit along the river, hydraulic parameters around the pool, and the High Plains aquifer flux into the pools.

The next model scenario examined the immediate impact on the alluvial aquifer due to the elimination of 18 pumps in operation within the alluvial aquifer. The immediate impact to the Arikaree River is due to the close proximity and the direct impact that these wells have on the river. The alluvial wells that are only approximately $1390 \mathrm{~m}$ (\#10741) from the river could have flows returned to the Arikaree River within 30 to 45 days. The only impact on the High Plains aquifer is the change in gradients between the aquifer due to the reduced decline of the alluvial aquifer. This scenario creates a temporary rise in the alluvial aquifer due to the sudden increase in flows to the alluvium. The interaction of the High Plains aquifer and alluvial systems in post-development has equilibrium declining at $0.0791 \mathrm{~m} /$ year with constant pumping. When the pumping is stops, it creates a temporary increase and then could create another equilibrium decline at a rate of $0.0941 \mathrm{~m} /$ year according to the water balance model. This scenario could potentially extend the projected pool dry up time to approximately 30 years as shown in Figure 10.

The next model scenario evaluates what level of participation in the identified water conservation practices would be required to stop the decline in the High Plains aquifer (not including elimination of alluvial wells). The model developed included the top conservation alternatives from each of the five survey sections. The impacts to the High Plains aquifer and alluvial aquifer were modeled by reducing the quantity of water pumped to the sum of 44.8 million cubic meters due to conservation measures. It was determined that, in order to stop the decline of the High Plains aquifer water tables it would require $77 \%$ participation of local farmers in the project area. Participation would require all participants to practice all five top identified conservation practices. At 77\% participation, there would need to be approximately 9446 ha implemented with the most feasible conservation alternatives (no-till, low-pressure sprinkler package, drought tolerant crops, water use limits, and conversion to dry beans). Based on the water balance model results, stopping the decline of the High Plains aquifer would also stop the decline of the alluvial aquifer (Figure 11). The elimination of the High Plains aquifer decline will allow a constant groundwater flux out of the High Plains aquifer into the alluvial aquifer. This constant flux into the alluvial aquifer will potentially bring the system back into equilibrium. This equilibrium rate will be at a significantly lower level than the pre-development equilibrium prior to irrigation pumping. $77 \%$ participation would be difficult to achieve without mandatory implementation

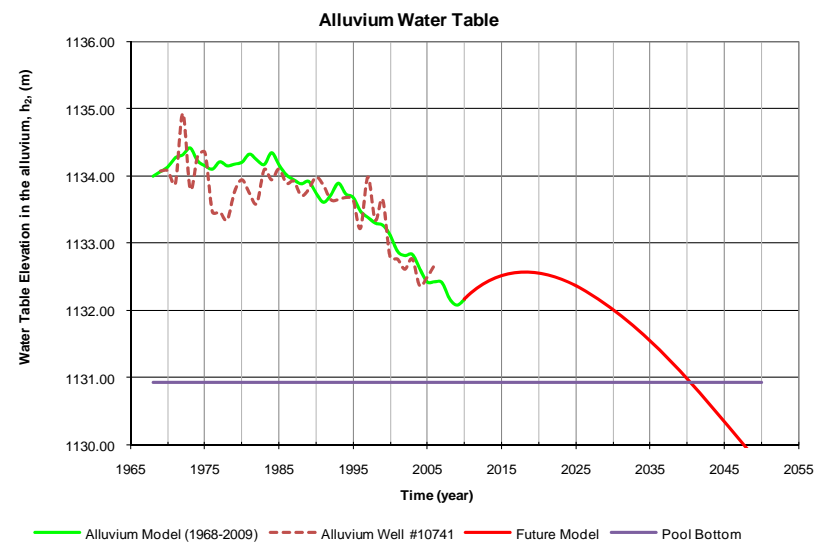

Figure 10. Alluvium aquifer water balance model with removal of alluvial wells and projected into future to 2050 . 


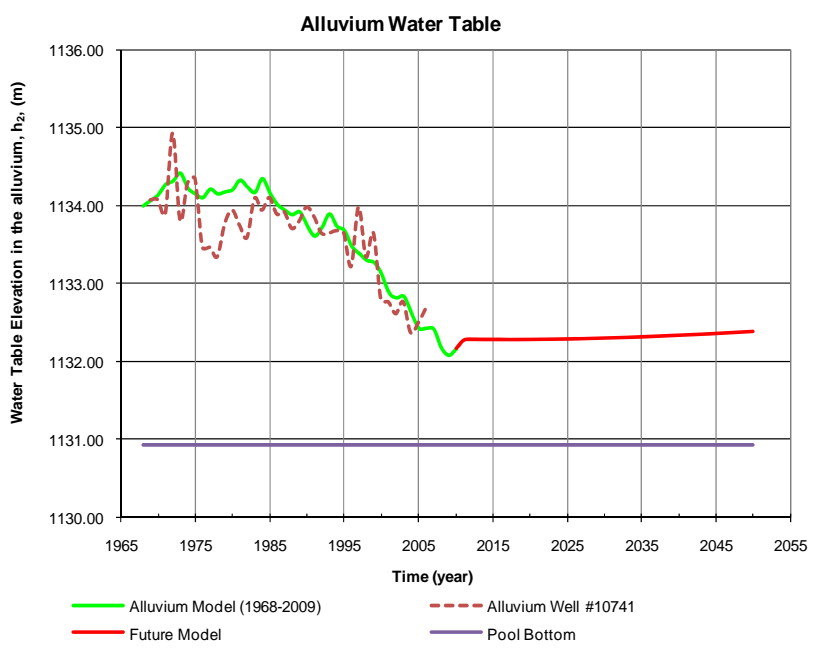

Figure 11. Alluvium aquifer water balance model with $77 \%$ future local farmer participation and projected into future to 2050 .

throughout the basin. The water balance model demonstrated that pumping would need to be reduced by at least 44.8 million cubic meters or $62.9 \%$ to maintain the current High Plains aquifer water levels and alluvial aquifer.

This scenario examined what level of future farmer participation would be required to delay the habitat pool drying from the estimated current drying time of 10 years to 20, 30, and 40 years (Figure 12). The required conservation participation to extend the pools another 20 years will require future participation of approximately $43 \%$. Water conservation over the extended time of 30 years would need $57 \%$ participation. The next extended time period would be 40 years with compulsory water conservation at approximately $62 \%$ participation. Table 1 shows the potential water conservation savings for each conservation alternative based on the different level of farmer participation. The water savings impacts for extending the habit pool drying by 20,30 , and 40 years are shown in Table 2.

\section{Conclusions}

The relationship between the High Plains aquifer and the alluvial aquifer is important when looking at long term drying trends in the Arikaree River. The High Plains aquifer is primarily recharged in the dune sands. Groundwater flux that occurs from the High Plains aquifer to the alluvium significantly affects the water balance and the consequent water table elevation in the alluvium. The groundwater flux between the High Plains aquifer and alluvium aquifer was studied by combining the water balance data and Darcy's Law for groundwater flow. Groundwater modeling examined flows at specific locations within the basin.

The High Plains aquifer and the alluvial aquifer affect the river on different time scales. The withdrawals from
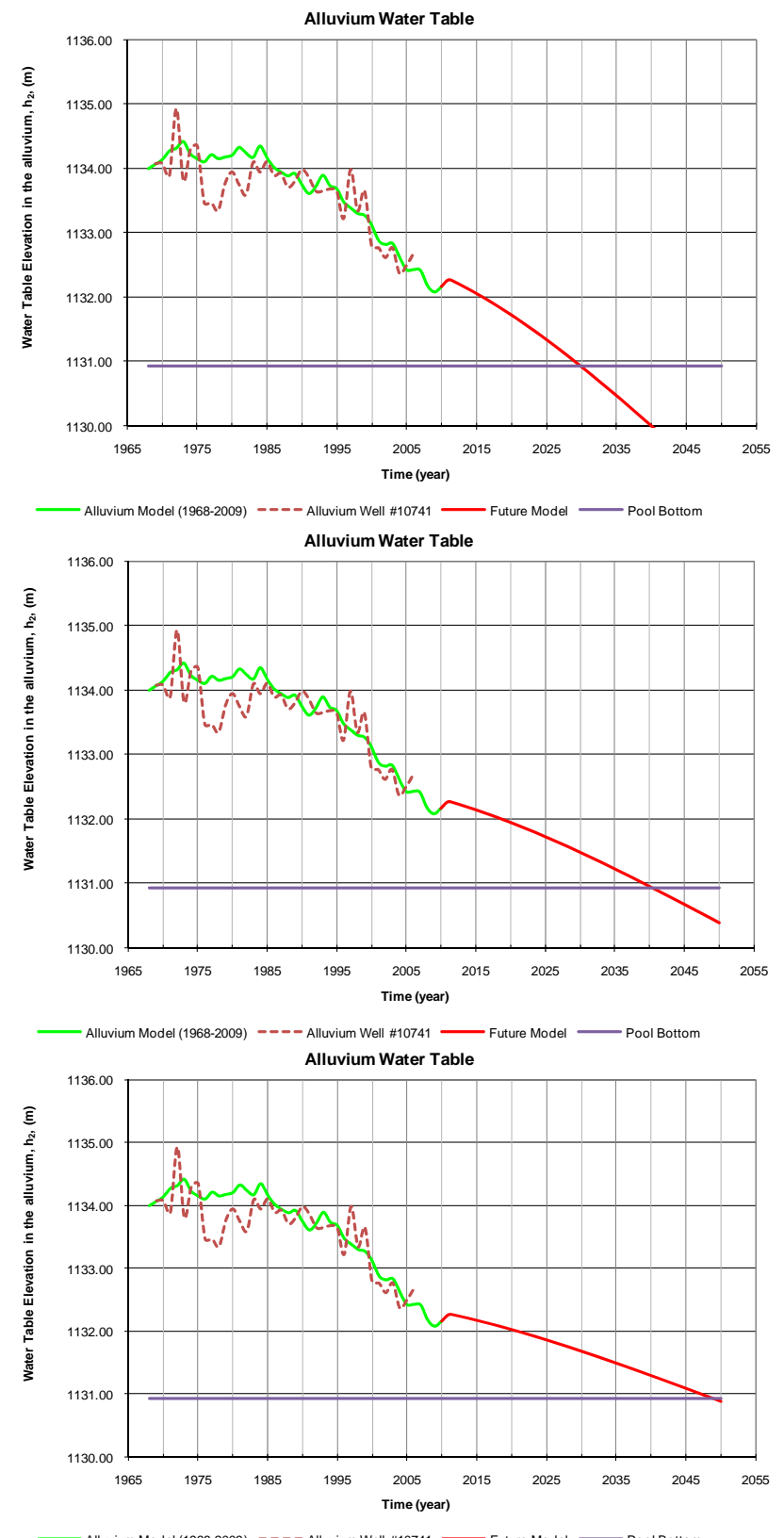

Figure 12. Alluvium aquifer water balance model with $43 \%$, $57 \%$, and $62 \%$ future local farmer participation and projected into future to 2050 .

the High Plains aquifer affect the river annually while withdrawals from the alluvial aquifer due to irrigation pumping and riparian use affect the river daily throughout the growing season. The radius of influence of the irrigation wells from the High Plains aquifer does not intersect the river during one pumping season [8]. The cone of depression of these wells fills in by a change in storage in the High Plains aquifer. This change in storage causes a relatively constant decline in the High Plains aquifer water table elevation from year to year. As the High Plains aquifer water table elevation declines, there 
Table 1. Water savings of conservation alternatives with varying participation.

\begin{tabular}{ccccc}
\hline & $77 \%$ Future Participation & $62 \%$ Future Participation & $57 \%$ Future Participation & $43 \%$ Future Participation \\
\hline Conservation Alternative & Water Savings ( $\mathrm{m}^{3} /$ year) & Water Savings $\left(\mathrm{m}^{3} /\right.$ year $)$ & Water Savings $\left(\mathrm{m}^{3} /\right.$ year $)$ & Water Savings $\left(\mathrm{m}^{3} / \mathrm{year}\right)$ \\
No-Tillage & $3.72 \mathrm{E}+06$ & $2.99 \mathrm{E}+06$ & $2.75 \mathrm{E}+06$ & $2.08 \mathrm{E}+06$ \\
Low Pressure Sprinkler & $5.46 \mathrm{E}+06$ & $4.40 \mathrm{E}+06$ & $4.05 \mathrm{E}+06$ & $3.05 \mathrm{E}+06$ \\
$\begin{array}{c}\text { Package } \\
\text { Drought Tolerant Crops }\end{array}$ & $6.35 \mathrm{E}+06$ & $5.11 \mathrm{E}+06$ & $4.70 \mathrm{E}+06$ & $3.54 \mathrm{E}+06$ \\
Water Use Limits & $2.07 \mathrm{E}+07$ & $1.67 \mathrm{E}+07$ & $1.53 \mathrm{E}+07$ & $1.16 \mathrm{E}+07$ \\
Converting to Dry Beans & $1.05 \mathrm{E}+07$ & $8.42 \mathrm{E}+06$ & $7.74 \mathrm{E}+06$ & $5.84 \mathrm{E}+06$ \\
Total & $4.67 \mathrm{E}+07$ & $3.76 \mathrm{E}+07$ & $3.46 \mathrm{E}+07$ & $2.61 \mathrm{E}+07$ \\
\hline
\end{tabular}

Table 2. Water savings and economic impacts of varying participation.

\begin{tabular}{|c|c|c|c|}
\hline Conservation Action & $\begin{array}{c}\text { Water Conservation } \\
\text { Participation }(\%)\end{array}$ & $\begin{array}{c}\text { Arikaree River Habitat } \\
\text { Pool Drying (years) }\end{array}$ & Water Saved Over Research Area $\left(\mathrm{m}^{3} /\right.$ year $)$ \\
\hline No Action & $0 \%$ & 2020 & $0 \mathrm{E}+00$ \\
\hline Removal of 18 Alluvial Wells & & 2040 & $6.68 \mathrm{E}+06$ \\
\hline Participation by Local Farmer & $43 \%$ & 2030 & $2.61 \mathrm{E}+07$ \\
\hline Participation by Local Farmer & $57 \%$ & 2040 & $3.46 \mathrm{E}+07$ \\
\hline Participation by Local Farmer & $62 \%$ & 2050 & $3.76 \mathrm{E}+07$ \\
\hline Participation by Local Farmer & $77 \%$ & $\infty$ & $4.67 \mathrm{E}+07$ \\
\hline
\end{tabular}

is less groundwater flux from the High Plains aquifer to the alluvial aquifer. This reduction in groundwater flux causes a deficit water balance in the alluvium that reduces the alluvial water table elevation and river stage at the beginning of each season in comparison to the elevations at the beginning of the previous season.

The Arikaree River is one of the last strongholds for Colorado's threatened Brassy Minnow (Hybognathus hankinsoni). Declining alluvial groundwater levels due to irrigation pumping have been shown to have negative effects that extend beyond the aquatic ecosystem in the Arikaree River. The riparian habitat areas along the Arikaree River are a critical component of stream-riparian ecosystems in the Great Plains [1]. Overall, declining alluvial groundwater levels will have far-reaching, negative effects across both terrestrial and aquatic ecosystems in the Arikaree River basin. The evidence presented here indicates that unless there is immediate action taken to counteract the decline in the High Plains aquifer, irrigation operations within the High Plains aquifer will eventually terminate and flows in the Arikaree River will cease.

\section{Acknowledgements}

We thank William Burnidge, a Northeast Colorado Project Director for The Nature Conservancy for the use and assistance of the Fox Ranch. Gregg Stults a local farmer in Yuma County for his tour of the Arikaree River. We also would like to thank the Central Yuma County Groundwater Management District for participation in the water conservation survey. Funding of this research was provided by Colorado Agricultural Experiment Station.

\section{REFERENCES}

[1] S. B. Rood, J. H. Braatne and F. M. R. Hughes, "Ecophysiology of Riparian Cottonwoods: Stream Flow Dependency, Water Relations and Restoration," Tree Physiology, Vol. 23, No. 16, 2003, pp. 1113-1124. doi:10.1093/treephys/23.16.1113

[2] W. G. Weist, "Geology and Ground-Water Resources of Yuma County, Colorado, USGS Water-Supply Paper 1539-J," United States Government Printing Office, Washington DC, 1964, pp. 1-52.

[3] E. Wachob, "Irrigation Pumping, Riparian Evapotranspiration, and the Arikaree River, Yuma County, Colorado," MS Thesis, Colorado State University, Fort Collins, 2006.

[4] J. A. Scheurer, K. D. Fausch and K. R. Bestgen, "Multiscale Processes Regulate Brassy Minnow Persistence in a Great Plains River," Transactions of the American Fisheries Society, Vol. 132, No. 5, 2003, pp. 840-855. doi:10.1577/T02-037

[5] US Geological Survey, "High Plains Regional Ground Water Study," 2008. http://co.water.usgs.gov/nawqa/hpgw/HPGW_home.html

[6] D. E. Kromm and S. E. White, "Groundwater Exploita- 
tion in the High Plains," University Press of Kansas, Lawrence.

[7] K. D. Fausch and K. R. Bestgen, "Global Biodiversity in a Changing Environment: Ecology of Fishes Indigenous to the Central and Southwestern Great Plains," SpringerVerlag, New York, 1997.

[8] A. Squires, "Groundwater Response Functions and Water Balances for Parameter Estimation and Stream Habitat Modeling," MS Thesis, Colorado State University, Fort Collins, 2007.

[9] M. P. Schaubs, "Ground Water Levels in the Northern High Plains Designed Ground Water Basins 2007," Colorado Division of Water Resources, Denver, 2007.

[10] G. VanSlyke and J. Stevens, "Depletion to the Ogallala Aquifer, Northern High Plains Designated Ground Water Basin," State Engineers Office, Colorado, 1990.

[11] Colorado Division of Water Resources, "Ground Water Levels, Northern High Plains Designated Ground Water Basin," State Engineers Office, Denver, 2002.

[12] US Geological Survey. "USGS Water Data for the Nation," 2010

http://waterdata.usgs.gov/ne/nwis/uv/?site_no $=06821500$ \&PARAmeter_cd $=00065,00060$

[13] T. Davis and S. Richrath, "Republican River Conservation Reserve Enhancement Program," Colorado Division of Wildlife and Colorado Division of Water Resources, State of Colorado, 2005.

[14] Food and Agriculture Organization, "Conservation in Arid and Semi-Arid Zones," Conservation Guide 3, Rome, 1976.

[15] N. L. Klocke, R. S. Currie and T. J. Dumler, "Water Saving from Crop Residue Management," Proceedings of Central Plains Irrigation Short Course and Exposition, Greeley, 19-20 February 2008, pp. 71-79.

[16] D. C. Nielsen, "Crop Residue and Soil Water" Central Plains Irrigation Conference \& Exposition Proceedings, Sterling, 16-17 February 2005, pp. 80-83.

[17] R. N. Klein, "Improving Your Success in No-Till. In Cover Your Acres Proceedings," Kansas State Research and Extension, Oberlin, 22-23 January 2008, pp. 22-26.

[18] N. L. Klocke, R. S. Currie and T. J. Dumler, "Effect of Crop Residue on Sprinkler Irrigation Management," Central Plains Irrigation Conference \& Exposition Proceedings, Colby, 21-22 February 2006, pp. 115-121.

[19] R. Oad, L. Garcia, K. Kinzli, D. Patterson and N. Shafike, "Decision Support Systems for Efficient Irrigation in the Middle Rio Grande Valley," Journal of Irrigation and Drainage Engineering, Vol. 135, No. 2, 2009, pp. 177185. doi:10.1061/(ASCE)0733-9437(2009)135:2(177)

[20] R. Oad, and K. Kinzli, "SCADA Employed in Middle Rio Grande Valley to Help deliver Water Efficiently," Colorado Water-Newsletter of the Water Center of Colorado State University, Fort Collins, 2006.

[21] R. Oad and R. Kullman, "Managing Irrigated Agriculture for Better River Ecosystems: A Case Study of the Middle Rio Grande," Journal of Irrigation and Drainage Engineering, Vol. 132, No. 6, 2006, pp. 579-586. doi:10.1061/(ASCE)0733-9437(2006)132:6(579)
[22] R. Barta, I. Broner, J. Schneekloth and R. Waskom, "Colorado High Plains Irrigation Practices Guide: Water Saving Options for Irrigators in Eastern Colorado," Colorado Water Resources Research Institute, Special Report No. 14, Colorado State University, Fort Collins, 2004.

[23] United States Department of Agriculture, "2007 Census of Agriculture: Yuma County Profile,” 2010.

http://www.agcensus.usda.gov/Publications/2007/Full_Re port/Volume_1,_Chapter_2_County_Level/Colorado/inde x.asp

[24] W. M. Frasier, R. M. Waskom, D. L. Hoag and T. A. Bauder, "Irrigation Management in Colorado: Survey Data Findings" Water Center at Colorado State University, Fort Collins, 1999.

[25] L. New, A. Knutson and G. Fipps, "Chemigation with LEPA Center Pivots," American Society of Agricultural Engineers Publication 04-90, 1990, pp. 453-458.

[26] K. Hill, E. Segarra, R. T. Ervin and W. Lyle, "Low Energy Precision Application Irrigation for Cotton Production in the Texas Southern High Plains," Texas Journal of Agriculture and Natural Resources, Vol. 4, 1990, pp. 3941.

[27] A. D. Schneider, "Efficiency and Uniformity of the LEPA and Spray Sprinkler Methods," Transactions of the American Society of Agricultural Engineers, Vol. 43, No. 4, 2000, pp. 937-944.

[28] F. R. Lamm and H. L. Manges, "Partitioning of Sprinkler Irrigation Water by a Corn Canopy," Transactions of the American Society of Agricultural Engineers, Vol. 4, No. 4, 2000, pp. 909-918.

[29] M. Tollenaar, "Genetic Improvement in Grain Yield of Commercial Hybrids Grown in Ontario from 1959 to 1988," Crop Science, Vol. 29, No. 6, 1989, pp. 13651371.

doi:10.2135/cropsci1989.0011183X002900060007x

[30] M. Tollenaar and J. Wu, "Yield Improvement in Temperate Maize in Attributable to Greater Stress Tolerance," Crop Science, Vol. 39, No. 6, 1999, pp. 1597-1604. doi:10.2135/cropsci1999.3961597x

[31] P. M. O’Neill, J. F. Shanahan, J. S. Schepers and B. C. Caldwell, "Agronomic Responses of Corn Hybrids from Different Eras to Deficit and Adequate Levels of Water and Nitrogen," Agronomy Journal, Vol. 96, No. 6, 2004, pp. 1660-1667. doi:10.2134/agronj2004.1660

[32] K. Ledbetter, "AgriLife Research Breeder Develops Drought-Tolerant Corn," 2008. http://agnews.tamu.edu/showstory.php?id=664

[33] W. Xu and R. Lascano, "New Stress Tolerant Corn Germplasm for Higher Water Use Efficiency and Water Conservation," 2010.

http://www.twdb.state.tx.us/RWPG/rpgm_rpts/20053580 21_germplasm.pdf

[34] G. W. Hergert, G. Stone, D. Yonts and J. Schild, "Limited Irrigation Cropping Systems for Conserving Water Resources in the Pumpkin Creek Watershed," Central Plains Irrigation Conference \& Exposition Proceedings, Greeley, 19-20 February 2008, pp. 46-52.

[35] D. D. Adelman, “A Successful Water Conservation Pro- 
gram in a Semiarid Region of Nebraska," Journal of American Water Resources Association, Vol. 39, No. 5, 2003, pp. 1079-1092. doi:10.1111/j.1752-1688.2003.tb03694.x

[36] R. G. Borman, J. B. Linder, S. M. Bryn and J. Rutledge, "The Ogallala Aquifer in the Northern High Plains of Colorado-Saturated Thickness in 1980; Saturated Thickness Changes, Predevelopment to 1980; Hydraulic Conductivity; Specific Yield; and Predevelopment and 1980 Probable Well Yields, Hydrologic Investigation Atlas HA-671," U.S. Geological Survey, 1983.

[37] L. Riley, "Finding the Balance: A Case Study of Irrigation, Riparian Evapotranspiration, and Hydrology of the Arikaree River Basin," M.S. Thesis, Colorado State University, Fort Collins, 2009.

[38] R. J. Hanks, H. R. Gardner and R. L. Florian, "Evapotranspiration-Climate Relations for Several Crops in the Central Great Plains," Soil and Water Conservation Research Division, Agricultural Research Service, United States Department of Agriculture, Fort Collins and Akron, 1968.

[39] Willard Owens Consultants, "Ground Water Resources of the San Arroyo Creek Basin, Volume I Hydrogeology, Computer Modeling, Conclusions and Recommendations," Prepared for Morgan County Quality Water District, 1988.

[40] D. L. Reddell, "Distribution of Groundwater Recharge, Technical Report AER66-67DLR9," Agricultural Engineering Department, Colorado State University, Fort Collins, 1967, p. 132.

[41] M. Sophocleous, "Groundwater Recharge Estimation and Regionalization: The Great Bend Prairie of Central Kansas and its Recharge Statistics," Journal of Hydrology, Vol. 137, No. 1-4, 1992, pp. 113-140. doi:10.1016/0022-1694(92)90051-V

[42] L. Fardal, "Effects of Groundwater Pumping for Irrigation on Stream Properties of the Arikaree River on the
Colorado Plains," M.S. Thesis, Colorado State University, Fort Collins, 2003.

[43] S. Griffin, "Effect of Irrigation Practices on Stream Depletion in the Arikaree River, Eastern Colorado," M.S. Thesis, Colorado State University, Fort Collins, 2004.

[44] D. B. McWhorter and D. K. Sunada, "Ground-Water Hydrology and Hydraulics," Water Resources Publications, Highlands Ranch, Colorado, 1977.

[45] R. H. McCuen, Z. Knight and A. G. Cutter, "Evaluation of the Nash-Sutcliffe Efficiency Index," Journal of Hydrologic Engineering, Vol. 11, No. 6, 2006, pp. 596-602. doi:10.1061/(ASCE)1084-0699(2006)11:6(597)

[46] C. W. Downer and F. L. Ogden, "GSSHA: Model to Simulate Diverse Stream Flow Producing Processes," Journal Hydrologic Engineering, Vol. 9, No. 3, 2004, pp. 161-174. doi:10.1061/(ASCE)1084-0699(2004)9:3(161)

[47] S. Birikundavyi, R. Labib, H. T. Trung and J. Rousselle, "Performance of Neural Networks in Daily Streamflow Forecasting," Journal Hydrologic Engineering, Vol. 7, No. 5, 2002, pp. 392-398. doi:10.1061/(ASCE)1084-0699(2002)7:5(392)

[48] Colorado Agricultural Meteorological Network, "About CoAgMet," 2010. http://climate.colostate.edu/ coagmet/

[49] J. A. Falke, "Effects of Groundwater Withdrawal and Drought on Native Fishes and Their Habitats in the Arikaree River, Colorado," Ph.D. Thesis, Colorado State University, Fort Collins, 2009.

[50] J. A. Scheurer, K. R. Bestgen and K. D. Fausch, "Resolving Taxonomy and Historic Distribution for Conservation of Rare Great Plains Fishes: Hybognathus (Teleostei: Cyprinidae) in Eastern Colorado Basins," Copeia, Vol. 1, 2003, pp. 1-12. doi:10.1643/0045-8511(2003)003[0001:RTAHDF]2.0.C $\underline{\mathrm{O} ; 2}$ 